Bryant University

Bryant Digital Repository

\title{
Spectacle, Maintenance and Materiality: Women and Death in Modern Brittany
}

Maura Coughlin

Bryant University

Follow this and additional works at: https://digitalcommons.bryant.edu/eng_jou

\section{Recommended Citation}

Coughlin, Maura, "Spectacle, Maintenance and Materiality: Women and Death in Modern Brittany" (2013). English and Cultural Studies Journal Articles. Paper 41.

https://digitalcommons.bryant.edu/eng_jou/41

This Article is brought to you for free and open access by the English and Cultural Studies Faculty Publications and Research at Bryant Digital Repository. It has been accepted for inclusion in English and Cultural Studies Journal Articles by an authorized administrator of Bryant Digital Repository. For more information, please contact dcommons@bryant.edu. 


\section{Spectacle, Maintenance and Materiality: Women and Death in Modern Brittany}

Maura Coughlin

Struck by the tactile, literal and physical aspects of the culture of death in Brittany, many modern observers of Breton peasant women believed that they had encountered surviving vestiges of pre-modern death beliefs. Nineteenthand early twentieth-century images and texts depicting Breton women in mourning have primarily been discussed in terms of a taste for "primitivism" that positioned women's rituals and piety as seemingly "timeless." As part of a larger project that reconsiders this approach to the material and visual culture of mourning in Brittany, I aim, in this chapter, to draw a distinction between the desire of observers to interpret everyday rural life as outside of history and the ways that images and objects enabled the flow of modern life in Breton communities. I argue that the material and local particularities of peasant women's mourning practices constitute a "specific aesthetic economy"1 ${ }^{\prime 1}$ of rural genre, articulated in oral narratives, literature, popular imagery and Salon painting. Representations of two material interactions that women had with the culture of death in Brittany are my focus: the use of "skull boxes" to preserve the cranium of a loved one and the public, ritual attention paid to cemetery graves.

Two models of relational practice have informed my approach to women's material culture of death in Brittany. My first model comes from the "actornetwork theory" (ANT), initiated by philosopher Bruno Latour in the 1980s. ANT understands human subjects and material objects as engaged in networked relationships, and views nature and culture inextricably entwined in relational processes. ${ }^{2}$ ANT encourages thinking about how things such as mourning objects can work in social practice:

Things might authorize, allow, afford, encourage, permit, suggest, influence, block, render possible, forbid and so on. Actor-network theory is not the empty 
claim that objects do things instead of human actors: it simply says that no science of the social can even begin if the question of who and what participates in the action is not first of all thoroughly explored, even though it might mean letting elements in which, for the lack of a better term, we could call non-humans. ${ }^{3}$

The implications of imputing agency to the nonhuman in the constructivist and relational strategies of ANT have been most recently articulated (in the study of visual culture) by the recently formed group of medieval scholars, the Material Collective. They declare in their manifesto:

Our specific interests vary, but we are all committed to prioritizing the materiality of things, the relationships between those things and the human beings who experience them, and the intimacy of past and present moments in time.

As we celebrate, dwell in, and embrace the basic materiality of our objects, we work to find ways to foreground the material of the objects themselves into larger historical analysis. ${ }^{4}$

My interest in mourning objects such as the skull box and sites such as the graveyard comes from a similar desire to explore the agency of these things.

The second way in which I propose to view women's mourning practices comes from performative feminist eco-politics, as outlined by Mierle Laderman Ukeles in her "Maintenance Art Manifesto" of 1969. Ukeles' ecoart resists the valorization of male "productive" labor, when it means that women's repetitive "maintenance" labor is denigrated to the "timeless" realm of nature. ${ }^{5}$ As Ukeles observed, the former, in the case of artistic labor, produces valued creative objects, whereas the latter, while equally cultural, is most often ignored when done properly. Ukeles' performance works have foregrounded the maintenance labor of museum guards and sanitation workers (among others), making many forms of cultural labor visible and valuable. Because the "naturalness" of women's mourning and their maintenance of the cult of the dead has been over-determined in the visual and literary culture of modern Brittany, I read the embodied, ritual aspects of performances of mourning in public spaces - such as the village cemeteryas forms of relational female "maintenance" labor. Rather than being timeless or natural, these acts were adaptive to the everyday conditions of modern life on the Brittany coast and they gave form to the sense of loss that a death made in a community and they maintained the memory of the dead, even in the absence of a visible memorial for the deceased. For viewers, the legibility of these practices (and representations of them) depended upon viewers' visual literacy, familiarity with rural genre imagery or their experiences with Breton attitudes toward death.

A few years ago, Ronan Taburet (b. 1926), a lifelong resident of Brest, told me an anecdote from his youth:opyrighted Material 
It was in the 1940s, I was walking on a road in the north of Finistère that ran from the village of Saint Renan (pop. 2000) to Plouzané (pop. 300) about 10 kilometers away. An old woman walked along, carrying in her arms a closed, square wooden case, about $30 \mathrm{~cm}$ on each side. We began talking, and after exchanging words about the weather, the season and the length of the route, I asked her, "Aren't you weary, Madame Cozic, to be carrying that load?" "On no." she replied, "this is not heavy. It is the skull of my dead husband!"

Madame Cozic, who had been a widow for two decades, explained to me "I have no more family in Saint Renan. I am now going to Plouzané where I was born. And so I am bringing with me the skull of my husband, which I will place in the ossuary. Thus, I won't ever be alone! ${ }^{6}$

As we talked that afternoon about Breton art and popular culture, he used this story to demonstrate the persistence of the cult of the dead in Brittany in his own living memory. This elderly woman's attachment to the physical remains of her long-dead husband (and her faith in the consoling, material presence of his bones) seemed a clear example of the modern persistence of age-old Breton death practices. ${ }^{7}$

This unusual tale shocks modern sensibilities, unaccustomed to the sight of or physical contact with a named individual's skull. Although representations of skulls, "death's heads" or skeletons were commonly used reminders of mortality in Early Modern Europe in plague imagery, vanitas still lives and memento moris, Enlightenment thought in France initiated a general shift away from such literal allusions to the materiality of death. ${ }^{8}$ In his influential survey of modern attitudes toward death, The Hour of Our Death, Philippe Ariès argues that Brittany was slow to abandon the early modern practice of making a visually compelling display of the bones of the dead in ossuaries and upon catafalques within the church. ${ }^{9}$ When skull boxes were encountered by the modern travelers in Brittany discussed below, they seemed archaic, barbaric or primitive. However, the making and saving of the skull box was one of several particularly modern, local responses to the nature of death in Brittany. Because asserting modernity for this practice may seem inherently contradictory, I will attempt to unravel some of the ways in which this object and its materiality functioned as a conduit for memory that resisted the previous anonymity of burial.

Ariès notes that during the Medieval period, there was little emphasis on the literal site that the material body of the deceased occupied. ${ }^{10}$ Mass graves in the churchyard were used for the burial of those not important enough to merit placement under the paving stones of churches. By the fifteenth century, ossuaries came into use for the storage and display of older bones when burial grounds were reused. In the seventeenth century, official pressure was exerted (throughout France) to end the burial of all but the clergy and aristocracy within the sanctified space of the church; the mandated use of the cemetery encountered great resistance in Brittany. ${ }^{11}$ Breton historians Alain Croix and 
Fanch Roudaut have focused upon the cult of the dead as the "master key" to Breton culture, from the sixteenth to the late twentieth century. ${ }^{12}$

Long before Breton communities switched to churchyard burials, official French concerns for hygiene in the 1790s encouraged the further removal of cemeteries from village centers to the edges of populated areas. ${ }^{13}$ As Michel Foucault noted, a shift in cultural meaning followed: "[ $t$ ]he cemeteries ... came to constitute, no longer the sacred and immortal heart of the city, but the other city, where each family possesses its dark resting place."14 Napoleonic reform in 1804 eliminated the practice of burying large numbers of bodies in common graves, thereby giving every individual the right to solely occupy a grave. Even though these graves were commonly re-used after five or ten years, the new rules also granted more permanent paying "concessions." The bourgeois family plot and its decorated tombs became conceived of as privately held sites; historian Thomas Kselman tells us that "the construction and management of cemeteries constitute an essential element in the material culture of death, and therefore of French culture in general during the nineteenth century."15 The modern creation of a family tomb made available a material practice of displacement previously only available to the aristocracy in which a "decaying, natural body" was replaced by a "stable social body that was assured continuity." 16 Although much attention has been given to the monumental tombs of celebrities and members of the bourgeoisie in urban cemeteries such as Père Lachaise or Montparnasse in Paris, it was rare in nineteenth-century France for a grave of a lower-class individual to be marked by more than a temporary wooden or metal cross. ${ }^{17}$ Today, very few stone markers date prior to the Third Republic in Breton cemeteries.

In a travel diary of 1847, Gustave Flaubert describes a village cemetery on the Quiberon peninsula as:

filled to its utmost capacity and overflow[ing] into the street. The head stones are crowded together and invade and submerge one another, as if the corpses were uncomfortable in their graves and had lifted up their shoulders to escape from them. It suggests a petrified ocean, the tombs being the waves, and the crosses the masts of shipwrecked vessels. ${ }^{18}$

Congestion of the burial ground, Flaubert explains, is alleviated by the removal of bones to the ossuary that:

contains skeletons that have been exhumed in order to make room for other corpses. Who has said: "Life is a hostelry, and the grave is our home?" But these corpses do not remain in their graves, for they are only tenants and are ejected at the expiration of the lease. ${ }^{19}$

Because Breton churchyard cemeteries had limited space, bounded on all sides by the village, the translation of bones might happen as soon as five years after the initial burial. Up until the First World War, it was still common 
practice in Brittany for a body to temporarily occupy a grave in the parish close. ${ }^{20}$ The ossuary, or charnel house (located in the churchyard or attached to the church), was the receptacle of bones of the dead taken from graves in the churchyard, or from beneath the church floor itself. After a grave was exhumed, the skull might be separated from the other bones and put in a wooden box painted with the name of the dead and dates of life and age at death. These skull boxes are shaped like peaked-roof houses, or miniature ossuaries; the skull contained within is partially visible through a heartshaped window that pierces the small wooden shrine. It was placed in the church or in an ossuary niche where it functioned as a miniature tomb (or "stable social body") that both memorialized the departed individual and displayed the material remains of the deceased. ${ }^{21}$ As many skull boxes are much earlier in date than carved stone monuments in their nearby cemeteries, they can be read as local precedents for modern practices of memorializing the individual in death.

Flaubert, however, described this practice as a provincial and archaic effort to temporarily differentiate the individually marked skulls from the unmarked, unruly chaos of the mixed bones contained in the ossuary.

Around this charnel-house, where the heaps of bones resemble a mass of
fagots, is arranged, breast-high, a series of little black boxes, six inches square,
surmounted by a cross and cut out in the shape of a heart in front, so that one
can see the skulls inside. Above the heart-shaped opening are the following
words in painted letters: "This is the head of ---- ----, deceased on such and
such a day, in such and such a year." These heads belonged to persons of
a certain standing, and one would be considered an ungrateful son if, after
seven years, he did not give his parents' skulls the luxury of one of these little
black boxes. The remainder of the bodies is thrown into the bone-house, and
twenty-five years afterwards the heads are sent to join them. A few years ago
they tried to abolish the custom; but a riot ensued and the practice continued. ${ }^{22}$

Legal scholar Théophile Ducrocq in 1884 likewise described the boxes' role in the maintenance (le maintien) of ancient funeral practices: "the goal of the skull boxes is evident. They promiscuously steal from the charnel the noblest part of the human skeleton. In addition, a vigilant hand, mindful of accuracy, marks the name of that which it bears." 23 The medieval oblivion of the mass grave is avoided, and the skull, at least, remains marked with identity.

In that the skull box can be understood as a sort of "memory object," refashioned from the body, it has affinity with nineteenth-century mourning objects such as pictures, objects or jewelry made from a loved one's hair. However, hair, like skin and fingernails, is a renewable and expendable part of the body from the "dead margins of the self." 24 The nineteenth-century mourning object sorts and tidies bodily remains, making a representational image or object that (somewhat) elides its visceral or abject materialityo as ateprevious part of a living person. 


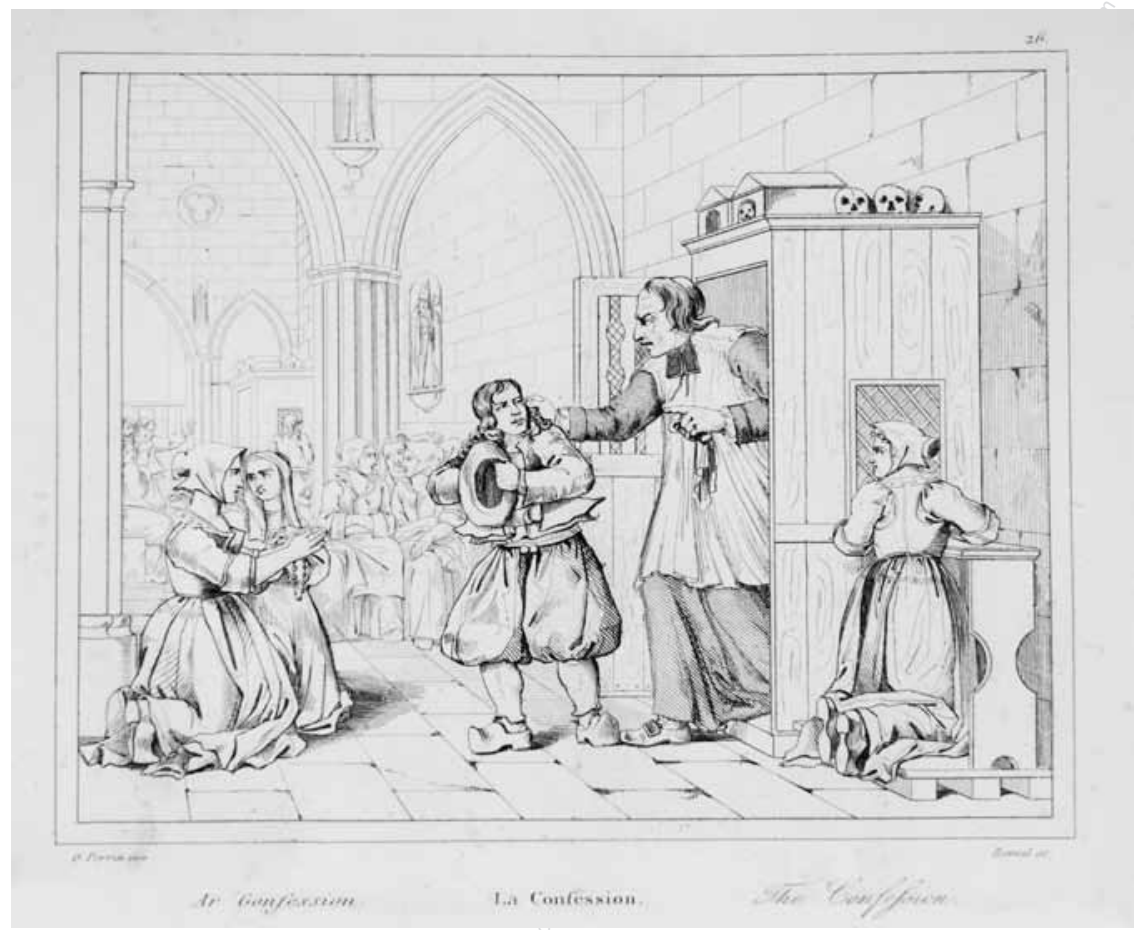

11.1 Olivier Perrin, Confession, from Galerie Bretonne, Ou Vie Des Bretons De L'armorique. Paris: I. Pesron, 1835. Photograph courtesy of the University of Massachusetts Amherst Image Collection Library

Yet unlike a picture, crafted of hair, and destined for domestic display, a skull box, no matter how well painted or constructed, is unavoidably grim in its function. In an essay of 1896 that details a ritual translation of bones from graves in the cemetery at Trégastel to its ossuary, Breton folklorist Charles Le Goffic explains that in Breton practice the term "relics" (reliques) refers to bones of the dead, without making distinction between the ordinary and the sanctified. ${ }^{25} \mathrm{~A}$ skull box, like a reliquary, has a window displaying its contents, but it is not an object that implies or promises a spiritual crossing over into the world of the miraculous (nor is it considered an "art object"). On the contrary, the tale of widow Cozic shows a devotion to memory that is literally embodied in the physical remains of her husband. Whereas reliquaries inspired pilgrims to travel to seek them out, this portable memorial, in which memory of the dead is invested, had to travel to remain close to home. The modern pattern of the aging and depopulation of the Breton countryside, continued to gain pace throughout the twentieth century; Widow Cozic's return with her box to the village of her childhood was part of this. 


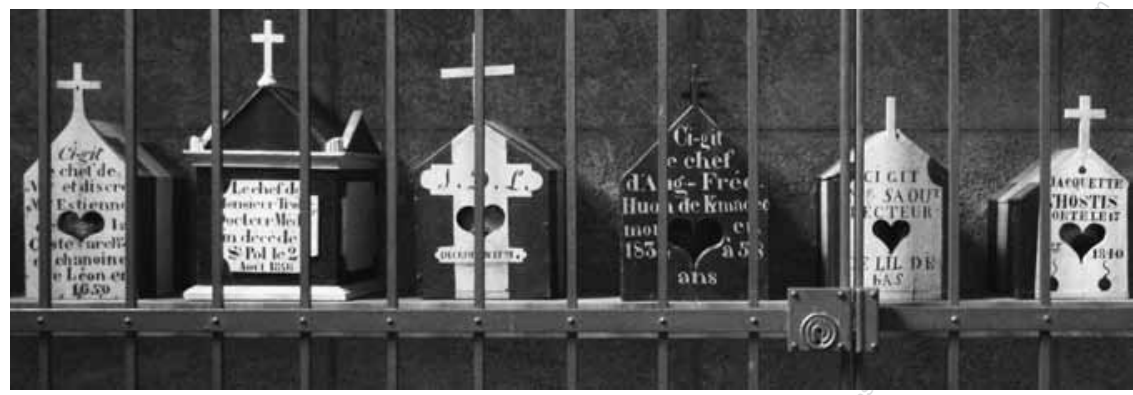

11.2 Skull boxes on display at the Cathedral of Paul Aurélien, Saint-Pol-de-Léon. Photo: author

Travel texts such as Ducrocq's and Flaubert's suggest that skull boxes were a common sight in churches and ossuaries in nineteenth-century Brittany, as does the even earlier illustration by Olivier Perrin (Figure 11.1), which depicts several of them in plain view atop a confessional. ${ }^{26}$ In Brittany today, only a few skull boxes can be seen on display: in the fifteenth-century church of Kermaria-an-Iskut (known for its exceptional Danse Macabre wall painting), in a side chapel in the cathedral of St. Pol de Leon (Figure 11.2), and in the ossuaries of St. Fiacre and Plouzélambre.

Outside of Brittany, the ossuary of the cemetery of St. Hilaire in Marville (Lorraine) has a large number of nineteenth-century skull boxes that testify to the spread of this practice from Brittany in the nineteenth century. ${ }^{27}$ Rather than understanding these as archaic or primitive things, in The Appointed Hour: Death, Worldview, and Social Change in Brittany (1989), sociologist Ellen Badone reads the Breton skull box as a local, modernizing practice that commemorated the individual, rather than mingling the material traces of the dead in the unmarked collective ossuary. ${ }^{28}$ She also reads the use of the skull box as part of a shift in Brittany away from imagery and objects that reminded the viewer of his or her own end (such as the legendary Grim Reaper of Brittany named Ankou) and toward the production of images, things and symbolic spaces that encouraged reflection on the departed. ${ }^{29}$

A full-page popular illustration from 1897 titled Le Jour des Morts en Bretagne (published in a color supplement to the topical, widely distributed illustrated French newspaper Le Petit Journal) can be read as emblematic of this transitional time (Figure 11.3). A young Breton woman in white head coiffe and black mourning cape kneels beside a flat gravestone, and behind her, other mourners in the cemetery kneel facing a stone ossuary whose arcades frame skull boxes. ${ }^{30}$ In the late nineteenth and early twentieth centuries, images of the cult of the dead often appeared as seasonal themes in the French popular press; scenes of grieving in the cemeteries of coastal Brittany appeared in late October or early November publications, coinciding with Toussaint, the national holidayd of remembrance for the dead. ${ }^{31}$ 


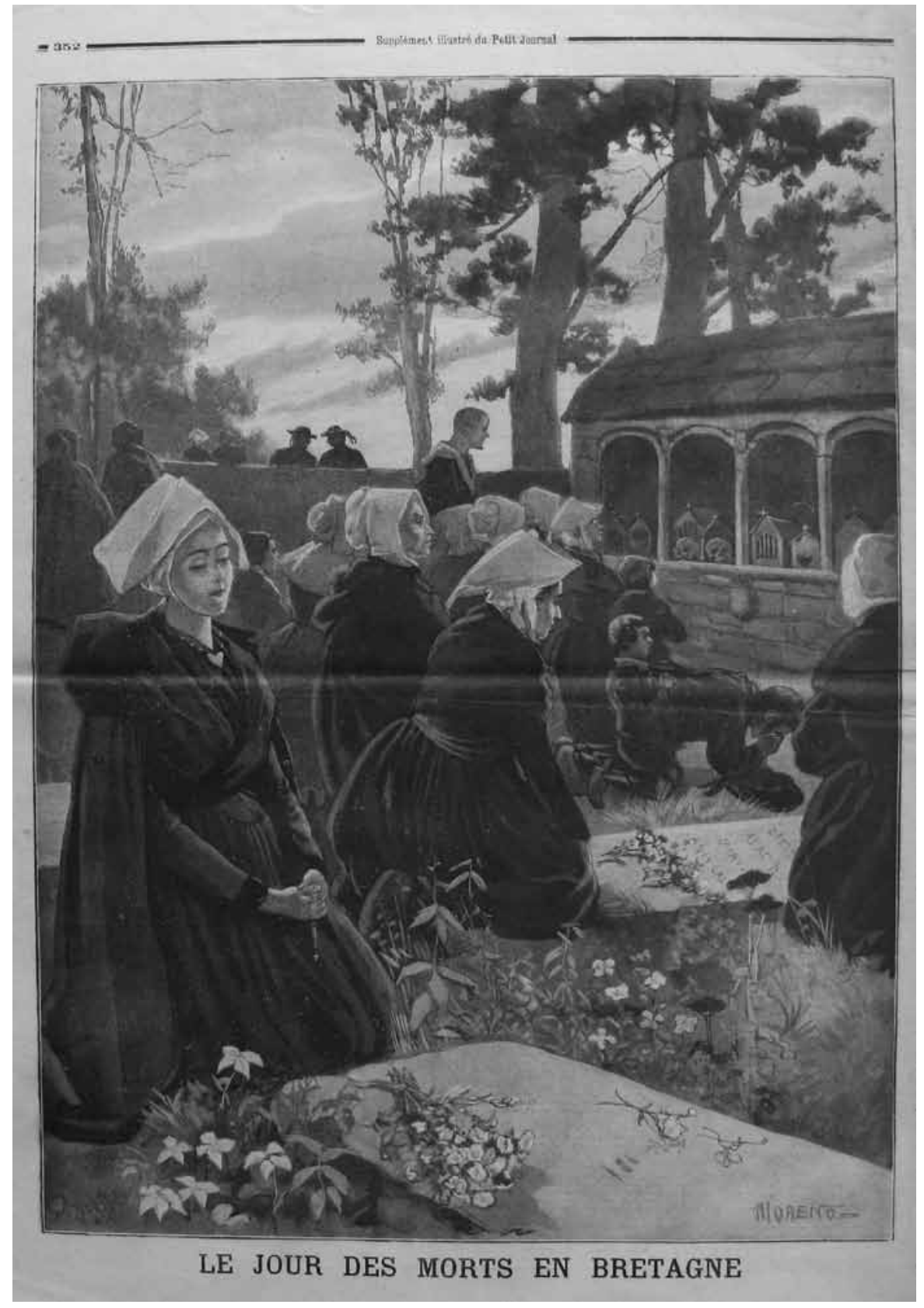

11.3 Moreno, The Day of the Dead in Brittany, Illustrated Supplement to Le Petit Journal, 31 October, 1897. Collection of the author

Copyright material: You are not permitted to transmit this file in any format or media; it may not be resold or reused without prior agreement with Ashgate Publishing and may not be placed on any publicly accessible or commercial servers. 
The skull boxes in this illustration might read very differently depending upon the viewer's relationship to Breton death practices. A Breton viewer (like Perrin) might identify two phases of the body after death - the recent burial beneath the slab in the graveyard and the implied second treatment of the body in the skull box beyond. For the tourist to the region (such as Flaubert), the ossuary in the background might signify grisly death practices of the past, juxtaposed with a much more familiar, romantic cemetery burial in the foreground.

As part of the effort to promote modern standards of hygiene, and to end the use of common burial grounds as spaces of commerce, festivity or the grazing of animals, most French cemeteries were surrounded by stone walls. ${ }^{32}$ Modern, enclosed cemetery space was thus marked out from the everyday as a meditative, restful place. For Foucault the "heterotopic" space of the older cemetery that was more integrated with the community was being lost in modern times:

Until the end of the eighteenth century, the cemetery was placed at the heart of the city, next to the church. In it there was a hierarchy of possible tombs. There was the charnel house in which bodies lost the last traces of individuality, there were a few individual tombs and then there were the tombs inside the church ... This cemetery housed inside the sacred space of the church has taken on a quite different cast in modern civilizations, and curiously, it is in a time when civilization has become "atheistic," as one says very crudely, that western culture has established what is termed the cult of the dead. ${ }^{33}$

But as Breton memoirist, Pierre-Jakez Hélias (1914-1995) describes, there were many social functions served by the spectacle of women's piety in the Breton cemetery:

on Sundays, at the end of each Mass and even, after Vespers, there were more of the living than the dead in the cemetery, all of whom were bent on greeting their own deceased before taking off to listen to a public announcement of the news or to savor some coffee, bread, and butter. And during burials, what better way is there to honor the newly dead than to meditate on the rectangle of land that covers your own and that will cover you yourself when the time comes? Besides, saying prayers for the dead never stopped the people from talking about one thing or another, spreading a little gossip or moaning about the decline in the price of pigs - all subjects that would have greatly interested the buried, had they been able to hear. ${ }^{34}$

Both Foucault's and Hélias's narratives are relevant to the Petit Journal image: in this we can see that, following modern convention, a solid and high wall screens the graveyard from the village, yet Breton men and women in traditional costume are conversing on either side of it. In spite of the modern wall, this space has remained public and sociable. A brief passage accompanying this illustration makes no temporal distinctions 
between the skulls and the fresher graves; instead the reader is told that this is a timeless tradition: "no where is the cult of the dead more alive than in Brittany." ${ }^{35}$ This text proclaims that these material remains in the cemetery, honored on this day of remembrance, are the exception to the rule of death at sea in coastal Brittany: "in the cemetery separated from the road by a low wall, as twilight comes, praying and crying before the ossuaries, one still sees those for whom, alas! the sea had at least the generosity to return the corpses of their men, the fathers, brothers, husbands and fiancées that it had taken away forever." ${ }^{\prime 36}$

The sentimental cemetery visit was often framed by travel writers or folklorists as a timeless aspect of the cult of death, yet in Brittany it participated in a modern cultural turn. Historian Thomas Kselman writes that the emerging modern funeral culture professionalized and commercialized death practices and distanced the participant from the material decay of the body. In France at large, the practice of visiting a graveyard on Toussaint, he writes, had increasing appeal as a secular, familial, and community-oriented act of remembrance: "nineteenth-century cemeteries gave people an opportunity to express in public their most intensely felt commitments - to class, confession and family." ${ }^{37}$

In his widely read memoir, Hélias describes the social expectation that women maintain the memory of the dead and properly display their piety in public: "[o]n Saturdays the women would get busy with pitchers, shovels, and knives in order to clean up the plot, afraid of what the gossips would say if, the next day, after High Mass, they noticed that you'd been neglecting your duties to the dead. Why you'd be covered with shame!"38 In most visual and literary representation of death in Brittany, it is almost exclusively the role of rural women to publicly suffer the pain of loss, manifest grief in bodily gestures, songs, prayers and other actions. ${ }^{39}$ They prepare bodies of the dead for burial; they display remembrance by wearing mourning garb, sitting at wakes, consoling the bereaved, visiting the grave, performing pilgrimages and praying for the souls of the departed. All of these acts are forms of female maintenance labor that do not produce a lasting object but that are, nonetheless, site specific, conspicuously performative and material.

It is rare to find images of cemetery visits (of either men or women) in Brittany before the Third Republic. But from 1870 to 1914, many forms of visual culture participated in both feminizing the provincial theatrical space of the enclosed cemetery and producing a lasting image of this ritual practice. What follows is a brief examination of several images of women performing their piety to the cult of the dead. In a much damaged triptych fresco from about 1870, painted in the former ossuary of the parish enclosure of St. Servais (Finistère), the mostly self-taught Breton artist and illustrator Yan Dargent represents a scene of women's piety for the dead (Figure 11.4). 


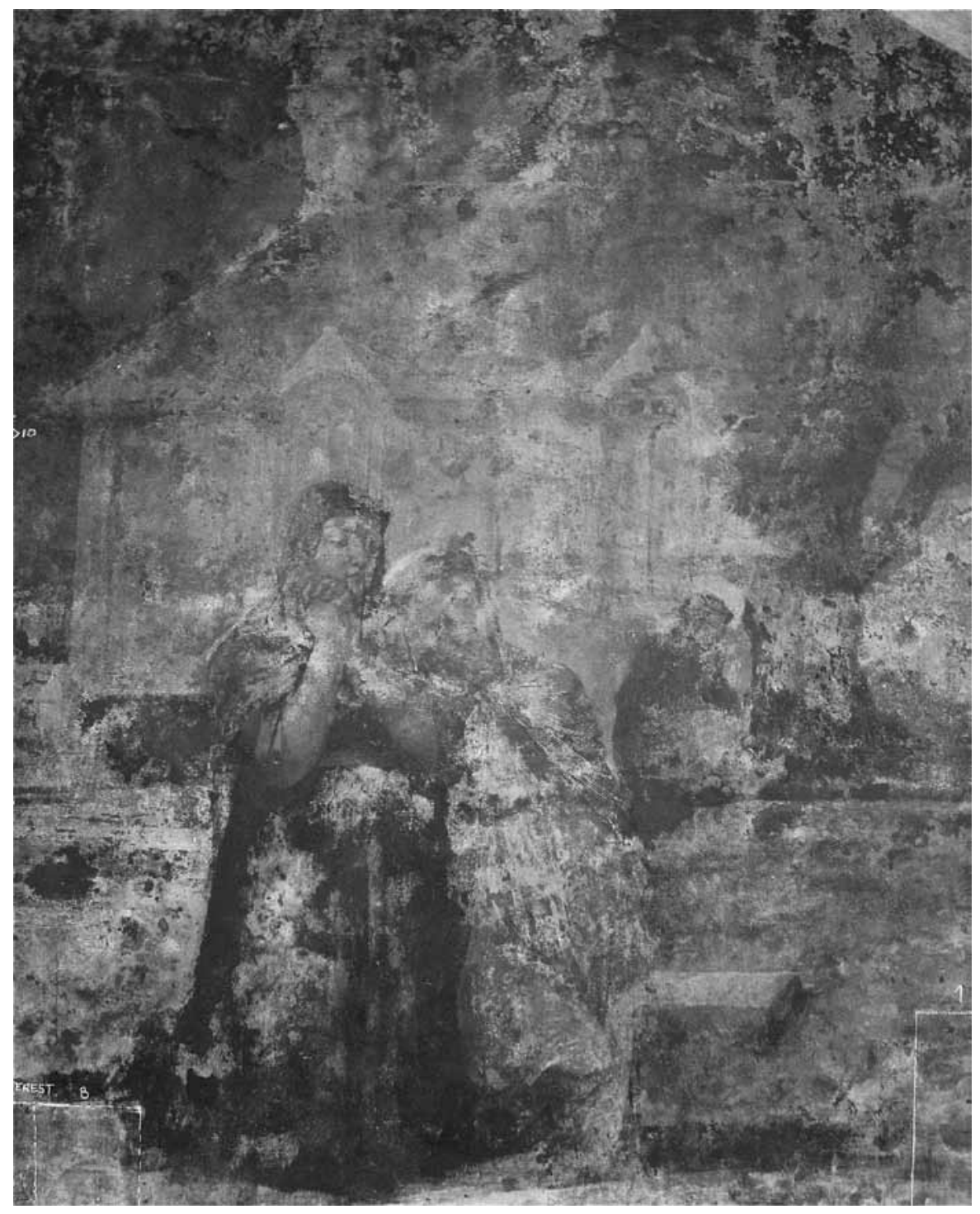

11.4 Yan' Dargent (Jean-Édouard Dargent), Piety for the Dead, c. 1870. Oil on plaster painting (in restoration) in the ossuary of the church of Saint-Servais, Finistère. Courtesy of the Musée Yan' Dargent. Photo: author

(C) Maureen Daly Goggin and Beth Fowkes Tobin and the contributors (2013)

From Maureen Daly Goggin and Beth Fowkes Tobin (eds), Women and the Material Culture of Death, published by Ashgate Publishing. See: http://www.ashgate.com/isbn/9781409444169 
Subtitled in Breton "prayer and the giving of alms delivers the soul from evil," 40 the cemetery image is paired with a scene of female charity; together they speak of the duties of Christian women in their hopes for salvation. In the foreground of the former scene, two kneeling young women lean against each other, heads thrown back and hands clasped in prayer. Around them are graves, capped with large rectangular stones that seem placed on, rather than planted in the ground. Behind them, the pointed window arches of St. Servais's seventeenth-century church are visible. Over their shoulders, a silhouetted, black-cloaked widow kneels in prayer upon another grave. ${ }^{41}$ Dargent clearly articulates the specific site of this image: the very churchyard beyond the wall upon which it is painted.

Three images from the 1890s repeat the theme of displaying public morality and maintaining memory at the grave: a color woodcut by Henri Riviere, Church and Cemetery at Perros-Guirec (1891, Departmental Breton Museum Quimper), a color etching by the Pont Aven artist Emile Dezaunay, Leaving Mass at Bannalec (c. 1892, private collection) and After the Mass, Brittany, a salon painting by naturalist painter Armand-Eugène Bach (1893, Fine Arts Museum Quimper). Despite their stylistic differences, all three images depict women, dressed in local costume, observed in the churchyard, after Sunday mass, paying respects to the dead. On the newly dug earth of these graves, as in the Dargent fresco, many flat flagstones have been laid. Wooden crosses lean in a haphazard fashion and only a few, more permanent monuments are visible. The women represented are thus mourning the recently deceased-those who occupy these graves temporarily, not eternally. This theme may have appealed to the widespread taste of Breton peasant "primitivism" at the turn of the century, yet the sentimental cemetery visits they depicted were modern aspects of women's rural village culture that maintained social connections of family and community.

\section{Conclusion}

The story of widow Cozic, on the road with her skull box in the 1940s, shows us that when women honored their memory of the dead and performed their piety they worked to maintain material connections to place.

The fascination of spectators with the rituals and beliefs of women's lives in Brittany was itself a modern phenomenon, shot through with nostalgia for a "primitive" rural world that seemed to be traditionally connected to the cycles of nature. Rural modernity had its own place and its own material practices that did not necessarily register as such to those who watched, rather than lived it. 


\section{Acknowledgement}

I am very grateful to Ronan and Alain Taburet for their stories and hospitality in Brest; I would also like to thank Jean Berthou at the Yan' Dargent Museum in Saint-Servais, René le Bihan and Marie-Rose Prigent at the CRBC in Brest. Emily Gephart read and commented on several drafts of this chapter. All translations from French are mine unless noted otherwise.

\section{Notes}

1 I take the phrase from Griselda Pollock, who notes that "in the play of canons, it is one of the failures of art history to have been unable to account for the cultural significance of rural genre in general, and the majority of its specific aesthetic economies." Differencing the Canon: Feminist Desire and the Writing of Art's Histories (London, New York: Routledge, 1999), 50.

2 See Bruno Latour, Reassembling the Social: An Introduction to Actor-Network-Theory (Oxford: Oxford University Press, 2005).

3 René van der Duim, "Tourismscapes an Actor-Network Perspective," Annals of Tourism Research 34, no. 4 (October 2007): 963.

4 The Material Collective Manifesto, http://thematerialcollective.org/material-collective-manifesto/.

5 Helen Molesworth, "Cleaning Up in the 1970s: The Work of Judy Chicago, Mary Kelly and Mierle Laderman Ukeles," Rewriting Conceptual Art, ed. Michael Newman and Jon Bird (London: Reaktion, 1999), 107-22.

6 Ronan Taburet (b. 1926) is an art collector and retired doctor who grew up in Brest and Saint Renan. His story was transcribed for me by his son, Alain Taburet.

7 Jacques Cambry is one of the first travel writers to mention the practice of putting the skulls in wooden boxes: "niches de bois qu'autrefois on couvroit de fleurs et de couronnes, qu'a présent on arrose d'eau bénite." Jacques Cambry, Voyage dans la Finistère, ou État de ce département en 1794 et 1795 (Paris: Cercle Social, 1799), 262.

8 Philippe Ariès, The Hour of Our Death, trans. Helen Weaver (New York: Alfred A. Knopf, 1981), 393.

9 Ibid., 60.

10 Ibid., 62.

11 Joseph Bergin, Church, Society and Religious Change in France 1580-1730 (New Haven: Yale University Press, 2009), 214.

12 See Alain Croix and François Roudaut, Les Bretons, la mort et Dieu: de 1600 à nos jours (Paris: Messidor, 1984). For a succinct discussion of the body of literature on Brittany's death culture see Ellen Badone, The Appointed Hour: Death, Worldview and Social Change in Brittany (Berkeley and Los Angeles: University of California Press, 1989), 21-5.

13 Bergin, 215. Also see Thomas Kselman, Death and the Afterlife in Modern France (Princeton: Princeton University Press, 1993), 167.

14 Michel Foucault "Of Other Spaces" in The Visual Culture Reader, ed. Nicholas Mirzoeff (London and New York: Routledge, 2002), 233.

15 Kselman, 170.

16 Elizabeth Hallam and Jenny Hockey, Death, Memory, and Material Culture (Oxford and New York: Berg, 2001), 52.

17 Kselman, 206.

18 Gustave Flaubert and Maxine Du Camp, Over Strand and Field: A Record of Travel in Brittany. Translated by Katharine Prescott Wormeley (Chicago: Magee, 1904), 26. (First published as Par Les Champs et par les greves: (voyage en Bretagne): Accompagné de mélanges et fragments inédits. Paris: G. Charpentier et Cie, 1886.) 
19 Flaubert and Du Camp, 26. Although a bit taken aback by the unavoidably physical signs of the dead's presence in Breton villages and larger towns, Flaubert notes approvingly that the effect of this display is that the dead remain at the heart of everyday life. He compares this with the more secular Parisian exile of the dead to the city's abject margins - the space of slaughterhouses and night-soil manufacture, 44 .

20 Charles Le Goffic, “Gens de mer-Trois vigils des morts” Revue Bleue 19, no. 4/6 (7 Nov. 1896), 581. Badone, 135. I investigate this text in further detail in a forthcoming article "Sites of Absence and Presence: Tourism and the Morbid Material Culture of Death in Brittany" in Staging Violent Death: The Dark Performances of Thanatourism, ed. Brigitte Sion (New York: Seagull Books, forthcoming 2012).

21 Théophile Ducrocq, "Des ossuaires et des boîtes à crânes de la Bretagne armoricaine" Extrait des Mémoires de la Société des Antiquaires de l'Ouest, VII (1884) 4. Also see Badone 136; Aries, 60-61.

22 Flaubert and Du Camp, 26.

23 "Celui de ces usages qui est le plus répandu dans la Bretagne armoricaine nous présente, en effet, au sein de la France de nos jours, dans ce dernier quart du xixe siècle, le maintien de certaines pratiques funéraires des siècles passés." Ducrocq, 1 .... "Le but des bottes à crânes est manifeste. Elles ravissent à la promiscuité du charnier la partie la plus noble de l'ossature humaine. En outre, une main vigilante, et qui pense ne se tromper jamais, la marque du nom qu'elle a porté." Ducrocq, 4 .

24 Hallam and Hockey, 136.

25 Le Goffic, 580.

26 Olivier Perrin describes this practice, shocking though it may be to urban sentiments, as coming directly from "the somber cult of the Druids." Olivier S. Perrin, Galerie Bretonne, Ou Vie Des Bretons De L'armorique (Paris: I. Pesron, 1835), 135.

27 Paul Koudounaris The Empire of Death: A Cultural History of Ossuaries and Charnel Houses (New York: Thames \& Hudson, 2011), 102.

28 Badone, 137.

29 Ibid., 137.

30 The image is signed "Moreno." This Spanish illustrator produced many orientalist themes for this journal.

31 For a collection of Toussaint practices see Baron Gaëtan de Wismes, Les fêtes religieuses en Bretagne, coutumes, légendes, E superstitions (Nantes: Mellinet, Biroché \& Dautais, 1902) 129-38. Also see Frédéric Tanter, "Réflexions sur la mer, la mort et la foi en Bretagne (XIXe-XXe siècles," in Attitudes autour de la mort en Bretagne, XXe siècle-XXIe siècles: Actes de la journée d'études organisée par la section religion de l'institut culturel de Bretagne (Vannes: Institut culturel de Bretagne, 2005), 66.

32 Kselman, 201.

33 Foucault, 233.

34 Pierre Jakez Hélias, The Horse of Pride: Life in a Breton Village, translated by June Guicharnaud (New Haven: Yale University Press, 1978) 105.

35 Supplèment Illustré du Petit Journal (31 Oct. 1897).

36 “Nulle part le culte des morts n'est plus vif qu'en Bretagne. Dans le cimetière séparé de la route par un bas mur, alors que vient le crépuscule, on voit encore prier et pleurer devant les ossuaires celles à qui la mer a eu au moins la générosité de rendre les cadavres de leurs hommes celles aussi, hélas ! dont elle a pour jamais fait disparaître les pères, les frères, les époux ou les fiancés." Unsigned description of "Nos Gravures" Supplèment Illustré du Petit Journal (31 Oct. 1897), 351.

38 Hélias, 105.

39 Ford writes that the feminization of Catholicism in France "was in part a nineteenth-century construction and that the phenomenon was also a reflection of a perceived rejection of Catholicism by men, which threw women's religiosity into sharp relief." Caroline Ford, Divided Houses: Religion and Gender in Modern France (Ithaca: CornellUniversity Press, 2005), 6. 
40 Dominique Radufe, “Yan' Dargent et l'âme Bretonne” in Jean Berthou et al, Yan' Dargent 1824-1899 (Landerneau, 1989), 21.

41 The composition is more clearly discerned in the sketch for this image as reproduced in Yan' Dargent, 19. published by Ashgate Publishing. See: http://www.ashgate.com/isbn/9781409444169 
Copyright material: You are not permitted to transmit this file in any format or media; it may not be resold or reused without prior agreement with Ashgate Publishing and may not be placed on any publicly accessible or commercial servers. 